\title{
Could Eosinopenia be a simple, fast and reliable biomarker in diagnosis of Covid-19?
}

\section{Eozinopeni;, Covid-19 tanısında, basit, hızlı ve güivenilir bir biyobelirteç olabilir mi?}

\author{
Muzaffer Katar ${ }^{1}$, Osman Demir ${ }^{2}$
}

Tokat Gaziosmanpașa Üniversitesi, Tip Fakültesi, Tıbbi Biyokimya AD., Tokat, Türkiye

${ }^{2}$ Tokat Gaziosmanpaşa Üniversitesi, Tip Fakültesi, Biyoistatistik AD., Tokat, Türkiye

Corresponding author: Muzaffer Katar, Tokat Gaziosmanpaşa Üniversitesi, Tip Fakültesi, Tıbbi Biyokimya AD., Tokat, Türkiye

E-mail: drkatar@hotmail.com

Received/Accepted: November 07, 2020 /December 22, 2020

Conflict of interest: There is not a conflict of interest.

\begin{abstract}
SUMMARY
Objective: Monitoring CBC subsets, particularly eosinophils. and inflammation markers, during admission and treatment of severe COVID19 patients, can reveal key indicators of disease progression and stage to provide a basis for diagnosis and treatment for clinicians.

Method: Our study is a retrospective case-control study. After taking aproval of Ministry of Health and Ethics Committee, the recorded clinical, laboratory and radiological data of 30 patients who were diagnosed with Covid-19, between 15 March and 15 June 2020, were compared with 30 healthy person by using appropriate statistical methods.

Results: Both patients and conrols included $10(33.3 \%)$ females and 20 $(66.6 \%)$ males with a mean age of $57.2 \pm 15.46$ and $60.07 \pm 20.59$ respectively. Eosinophil counts of the patients on admission were significantly lower than the controls ( $\mathrm{p}<0.001)$. Eosinophil counts one week after admission were increased significantly compared to the admission levels $(p=0.004)$. Neutrophil/Eosinophil ratio, which is a reliable indicator of 'Eosinopenia' in patients on admission was significantly higher than that of one week later ( $\mathrm{p}=0.041)$. EO1, NE1, NE2, PLT2/LYM2, LYM1/CRP1 and LYM2/CRP2 were the most predictive indexes. The AUCs of them were; $0.856,0.778,0.719,0.738,0.747$ and 0.702 respectively, the cut-off values were; $0.04,3.32,3.21,144,59,1.99$ and 7.84 respectively, the sensitivity and specificity were $66.7 \%$ and $93.3 \%$ for $\mathrm{EO} 1 ; 53.3 \%$ and 93.3\% for NE1; $46.7 \%$ and $93.3 \%$ for NE2; and $80.1 \%$ and $80.5 \%$ for PLT2/LYM2; and $100 \%$ and $66.7 \%$ for LYM1/CRP1 and $100 \%$ and $53.3 \%$ for LYM2/CRP2; respectively.

Conclusions: Tracking of CBC subsets, particularly Eosinophil, and CBC indexes is helpful in the early screening, diagnosis, treatment and follow up of critical COVID-19 patients.
\end{abstract}

Muzaffer Katar

Osman Demir

Keywords: Covid-19, diagnosis, eosinopenia, lymphopenia, neutropenia.

ORCID IDs of the authors: M.K. 0000000262962390 O.D. 0000000213222716

\section{ÖZET}


Yöntem: Calıșmamız bir retrospektif vaka-kontrol çalıșmasıdır. Sağlık Bakanlığı ve Etik Kurul onayları alındıktan sonra; 15 Mart - 15 Haziran 2020 tarihleri arasında Covid-19 tanısı alan 30 hastanın kaydedilmiş klinik, laboratuvar ve radyolojik verileri uygun istatistiksel yöntemler kullanılarak 30 sağ lıklı kişi ile karșılaştıııldı.

Bulgular: Hem hastalar hem de kontroller sırasıyla $57.21 \pm 15.46$ ve $60.07 \pm 20.59$ yaş ortalamaları ile $10(\% 33.3)$ kadın ve 20 (\% 66.6) erkekten oluşuyordu. Hastaların bașvuru sırasındaki eozinofil sayıları kontrollere göre anlamlı derecede düşüktü ( $p<0.001)$. Yatıștan bir hafta sonraki eozinofil sayıları başvuru düzeylerine göre anlamlı derecede yükseldi $(p=$ 0,004). Başvuru (NEU1) ve bir hafta sonraki nötrofil sayıları (NEU2) kontrollerden anlamlı olarak düşüktü (sırasıyla $\mathrm{p}=0,009, \mathrm{p}=0,041$ ). Başvuru (LYM1) ve bir hafta sonraki lenfosit sayıları (LYM2) kontrollerden anlamlı olarak düşüktü ve başvuru seviyeleri bir hafta sonrasına göre anlamlı derecede düşüktü (sırasıly $p=0,001, p=0,033$ ve $p=0,022$ ). Bir hafta sonraki PLT2/LYM2 oranları kontrollerden ve başvuru anındaki PLT1/LYM1 oranlarından anlamlı derecede yüksekti (sirasiyla $\mathrm{p}=0.026$ ve $\mathrm{p}=0.020$ ). EO1, NE1, NE2, PLT2/LYM2, LYM1/CRP1 ve LYM2/CRP2; tan1 ve takipte prediktif değeri en yüksek indekslerdi. Bunların AUC'leri; sirasıyla $0.856,0.778,0.719,0,738,0.747$ ve 0.702 . Cut-off değerleri; sırasıyla $0.04,3,32,3,21,144,59,1.99$ ve 7.84 , duyarlılık ve özgüllükkleri; sırasıyla EO1 için \% 66.7 ve \%93.3, NE1 için \% 53,3 ve \% 93,3, NE2 için \% 46,7 ve \% 93,3 ve PLT2/ LYM2 için \% 80,1 ve \% 80,5, LYM1/CRP1 için \%100 ve $\% 67$ ve LYM2/CRP2 için \%100 ve \%53.3 idi.

Sonuç: CBC alt parametrelerinin, özellikle Eozinofil, ve CBC indekslerinin takibi kritik COVID-19 hastalarının erken taranması, tanıs1, tedavisi ve takibinde yardımc1 olur.

Anahtar sözcükler: Covid-19, eozinopeni, lenfopeni, nötrpeni, tanı

Bu çalışma Helsinki Deklarasyonuna uygun bir şekilde, Tokat Gaziosmanpaşa Üniversitesi Tıp Fakültesi Klinik Araştırmalar Etik Kurulu tarafından 20-KAEK-237 numarasıyla onaylandıktan sonra gerçekleştirilmiştir.

\section{INTRODUCTION}

Coronavirus SARS-Cov2 caused Covid-19 disease and it has reached pandemic rates in an extremely short period of time ${ }^{1}$. How SARS-CoV-2 causes infection is not yet fully understood. It is thought to have tendency for cells of the lower respiratory tract. Interhuman transmission of coronaviruses occurs mainly through direct and indirect contact through saliva droplets and surfaces. So similar to severe acute respiratory syndrome (SARS) and Middle East respiratory syndrome (MERS), COVID-19 seems to lead severe clinical pictures in humans, from mild malaise to death with acute respiratory distress syndrome ${ }^{2}$. Lymphopenia and eosinopenia are common during the disease process.

Complete Blood Count (CBC) subsets like; neutrophils (NE), lymphocytes (LYM), eosinophils (EO), monocytes (MO), platelets (PLT), mean platelet volume (MPV) and CBC indexes such as; neutrophil lymphocte ratio (NLR) and platelet lymphocyte ratio (PLR) and CReactive protein (CRP) are sensitive biomarkers of natural and systemic inflammation and, considered indicators of infection and systemic inflammation. Monitoring Covid-19 patients in terms of these CBC subsets and indexes in the course of treatment begining from on admission to the hospital to the discharge provides us prognostic values and important therapeutic targets.

One of important subset of $\mathrm{CBC}$, EOs are leukocytes located in the tissue or circulating in the peripheral blood and have a strong proinflammatory effect in many diseases. Recently, they have been shown to have various other functions such as immunoregulatory and antiviral effects. While EOs normally constitute a low proportion of leukocytes in circulation, such as 1$3 \%$, their amount may vary in some disease states 3 . Due to its proinflammatory properties, serum levels are associated with the clinical picture. Thanks to their properties such as antiviral response and organising various physiological responses, they also function as regulatory cells in protective immunity ${ }^{4}$. Eosinophil response affects the recommended treatment and care in Covid-19 patients. Eosinopenia has been reported previously in patients infected with Covid-19 caused by severe acute respiratory syndrome coronavirus-2 (SARSCoV-2) ${ }^{5}$. In the articles published recently, it was stated that the EO counts in severe Covid-19 patients decreased significantly. It was observed that the severity of the disease was related to the level of eosinopenia as well.

Covid-19 disease is diagnosed by molecular, serological or radiological methods. In cases where these diagnostic methods cannot be reached or take too long time to result, it is important to diagnose Covid-19 patients with simple and easily accessible laboratory biomarkers to give priority for laboratory and radiologic methods for suspected patients and to predict the course of the disease whether they will need intensive care or not. So that, the aim of this study is to examine and analyze the differences in CBC results of COVID-19 patients, particularly eosinophils, on admission and after a week of treatment to identify key indicators of disease progression and stage to provide a basis for diagnosis and treatment for clinicians. 


\section{MATERIAL AND METHODS}

Our study is a retrospective case-control study. After taking approval of Ministry of Health, it was approved by the Tokat Gaziosmanpasa Clinical Researches Ethics Committee with code of 20KAEK-237 on 17.09.2020. Although the gold standard of diagnosis in Covid-19 is reverse transcriptase polymerase chain reaction (RT-PCR), we also included patients diagnosed with other diagnostic methods like serologic tests or computerized tomography (CT). Our patient group included 30 Covid-19 patients diagnosed with any of those diagnostic methods between 15 March and 15 June 2020 . They were compared with 30 healthy controls paired with patients in terms of age and gender. Patients; those who have undergone bypass operation within the last month, those with a history of metabolic, malignant and rheumatic diseases and pregnants were not included in the control group.

All data of the patients were obtained retrospectively from archived medical file materials. The collected data includes demographic information, clinical medical history, accompanying diseases, signs and symptoms, laboratory findings and radiological imaging findings. The data of the hospitalization day of the patient was determined as "Admission day data" of the study. The data obtained at the end of one week after hospitalization were determined as "first week data". Radiological images were classified as mild, moderate, and severe according to the compatibleity with the findings of Covid-19.

Descriptive analyzes give information about the general characteristics of the study groups. The data of continuous variables are as mean \pm standard deviation; Data on categorical variables are given as $\mathrm{n}(\%)$. When comparing the means of quantitative variables between groups, the Significance test of the Difference Between Two Means was used for the normally distributed variable, and the Mann Whitney U test was used for the non-normally distributed variable. For within-group comparison, the significance test of the difference between the two partners was used for the normally distributed variable, and the Wilcoxon test was used for the non-normally distributed variable. The chi-square test is used to evaluate whether there is a relationship between qualitative variables. Pearson correlation coefficient is used for correlation between quantitative variables. When $\mathrm{p}$ counts were calculated less than 0.05 , it was regarded statistically significant. Ready-made statistics software was used for calculations (SPSS 22.0 Chicago, IL, USA).

\section{RESULTS}

Both of our patient and control groups consisted of $10(33.3 \%)$ women and $20(66.6 \%)$ men with a mean ages of $57.2 \pm 15.46$ and $60.07 \pm 20.59$ respectively. PCR tests of $20(66.6 \%)$ patients were positive, while that of $4(13.3 \%)$ patients was negative. Serologic tests were positive in $24(80 \%)$ patients. While the result of $24(92.3 \%)$ patients who underwent computerised tomography (CT) imaging was evaluated as compatible with the disease, $2(6.7 \%)$ of the patient was evaluated as negative. $22(73.3 \%)$ of the patients had fever at the time of presentation. The qualitative variable distributions according to the group are shown in Table 1.

In our study, the eosinophil counts (EO1) of the patients at the time of admission were found to be significantly lower than the controls $(\mathrm{p}<0.001)$. There was a significant increase in eosinophil levels (EO2) one week after admission, compared to the admission levels (EO1) ( $\mathrm{p}=0.004)$. A reliable demonstrator of eosinopenia, ratio of neutrophil to eosinophil on admission (NEU/EO1) was significantly higher than one week later $(\mathrm{NEU} / \mathrm{EO} 2)(\mathrm{p}=0.041)$. White Blood Cell $(\mathrm{WBC} 1)$ counts on admission were significantly lower than controls $(\mathrm{p}=0.007)$. Neutrophil (NEU1) counts on admission and one week later (NEU2) were significantly lower than those of controls $(\mathrm{p}=0.009$, $\mathrm{p}=0.041$, respectively). Lymphocyte (LYM1) counts on admission and one week later (LYM2) were significantly lower than those of controls and admission levels were significantly lower than those of one week later $(\mathrm{p}=0.001, \mathrm{p}=0.033$, and $\mathrm{p}=0.022$, respectively). Monocyte counts on admission (MO1) and one week later (MO2) were significantly lower than those of controls $(\mathrm{p}=0.010$ and $\mathrm{p}=0.049$ respectively). Basophil counts on admission (BAS1) and one week later (BAS2) were significantly lower than those of controls ( $p<$ 0.001 and $p<0.001$ respectively). Platelet counts on admission (PLT1) were significantly lower than those of controls and one week later $(\mathrm{p}=0.006$ and $\mathrm{p}=0.001$, respectively). EO1\% was significantly lower than $\mathrm{EO} 2 \%(\mathrm{p}=0.041)$. PLT2/LYM2 ratios were significantly higher than controls and admission PLT1/LYM1 ratios $(\mathrm{p}=0.026$ and $\mathrm{p}=0.020$, respectively). Ferritin levels on admission were significantly higher than controls and lower than one week later $(\mathrm{p}=0.033$ and $\mathrm{p}=0.011$, respectively). hs-CRP levels on admission were significantly higher than controls $(p=0.048)$. EO1, NE1, NE2, PLT2/LYM2, LYM1/CRP1 and LYM2/CRP2 were the most predictive indexes. The AUCs of them were; 0.856 , $0.778,0.719,0.738,0.747$ and 0.702 respectively, 
the cut-off values were; $0.04,3.32,3.21,144,59$, 1.99 and 7.84 respectively, the sensitivity and specificity were $66.7 \%$ and $93.3 \%$ for $\mathrm{EO} 1 ; 53.3 \%$ and $93.3 \%$ for NE1; $46.7 \%$ and $93.3 \%$ for NE2; and $80.1 \%$ and $80.5 \%$ for PLT2/LYM2; and for LYM1/CRP1; $100 \%$ and $66.7 \%$ and for LYM2/CRP2; $100 \%$ and $53.3 \%$ respectively.

Table 1: Distribution of qualitative variables of patient group

\begin{tabular}{|c|c|c|}
\hline \multicolumn{2}{|l|}{ Variables } & $\mathrm{n}(\%)$ \\
\hline \multirow[t]{2}{*}{ Gender } & Female & $10(33,3)$ \\
\hline & Male & $20(66,7)$ \\
\hline \multirow{2}{*}{ Discharge } & Discharged & $27(90.0)$ \\
\hline & Passed Away & $3(10.0)$ \\
\hline \multirow{2}{*}{ Chronical Lung Disease (CLD) } & None & $0(86.7)$ \\
\hline & Present & $4(13.3)$ \\
\hline \multirow{2}{*}{ Diabetes Mellitus (DM) } & None & $28(93,3)$ \\
\hline & Present & $2(6,7)$ \\
\hline \multirow{2}{*}{ Hypertension (HT) } & None & $0(80.0)$ \\
\hline & Present & $6(20.0)$ \\
\hline \multirow{2}{*}{ Cardio-Vascular Disease (CVD) } & None & $28(93,3)$ \\
\hline & Present & $2(6,7)$ \\
\hline \multirow{2}{*}{ Malignancy } & None & $28(93,3)$ \\
\hline & Present & $2(6,7)$ \\
\hline \multirow{2}{*}{ Serological Test Positivity } & Negative & $6(20.0)$ \\
\hline & Positive & $24(80.0)$ \\
\hline \multirow{2}{*}{ Polimerase Chain Reaction (PCR) } & Negative & $4(13,3)$ \\
\hline & positive & $20(66.6)$ \\
\hline \multirow{2}{*}{ Computed Tomography (CT) } & Incompatible & $2(6,7)$ \\
\hline & Compatible & $24(92,3)$ \\
\hline \multirow{2}{*}{ Clinical Condition (Admission) } & Mild-Moderate & $26(86,7)$ \\
\hline & Critical-Severe & $4(13,3)$ \\
\hline \multirow{2}{*}{ Clinical Condition (Mid-Treatment) } & Mild-Moderate & $22(73,3)$ \\
\hline & Critical-Severe & $8(26,7)$ \\
\hline \multirow{2}{*}{ Clinical Condition (After a week) } & Mild-Moderate & $24(80)$ \\
\hline & Critical-Severe & $6(20)$ \\
\hline \multirow{2}{*}{ Fever } & None & $8(26,7)$ \\
\hline & Present & $22(73,3)$ \\
\hline \multirow{2}{*}{ Dispnea } & None & $20(66.6)$ \\
\hline & Present & $10(33.3)$ \\
\hline \multirow{2}{*}{ Coughing } & None & $8(26,7)$ \\
\hline & Present & $22(73.3)$ \\
\hline \multirow{2}{*}{ Malaise } & None & $6(20.0)$ \\
\hline & Present & $24(80.0)$ \\
\hline
\end{tabular}

Data were expressed in numbers and percentages. Pearson's chi-square test was used.

The distribution of quantitative variables according to the group is shown in Table 2. In Figure 1,2 and 3; ROC analysis of EO1, NE1, NE2, PLT2/LYM2, LYM1/CRP1 and LYM2/CRP2 were shown.
While $3(10 \%)$ of the patients lost their lives during the treatment process, 27 (90\%) patients recovered and were discharged in our study. 
Table 2: Distribution of quantitative variables by groups

\begin{tabular}{|c|c|c|c|c|c|c|c|}
\hline \multirow{3}{*}{\multicolumn{2}{|c|}{ Variables }} & \multicolumn{5}{|c|}{ Group } & \multirow{3}{*}{$\mathrm{p}_{1}$} \\
\hline & & \multicolumn{3}{|c|}{ Control } & \multicolumn{2}{|r|}{ Patient } & \\
\hline & & \multicolumn{2}{|c|}{ Mean \pm SD } & Median[Q3-Q1] & Mean \pm SD & Median[Q3-Q1] & \\
\hline \multicolumn{2}{|l|}{ Age } & \multicolumn{2}{|c|}{$60,07 \pm 20,59$} & $66[42-75]$ & $57,2 \pm 15,46$ & $59[46-69]$ & 0,670 \\
\hline \multicolumn{2}{|l|}{$\mathrm{EO} 1\left(\mathrm{x} 10^{3} / \mu \mathrm{L}\right)$} & \multicolumn{2}{|c|}{$0,16 \pm 0,14$} & $0,09[0,06-0,24]$ & $0,04 \pm 0,03$ & $0,04[0,02-0,07]$ & $<0,001 *$ \\
\hline \multicolumn{2}{|l|}{$\mathrm{EO} 2\left(\mathrm{x} 10^{3} / \mu \mathrm{L}\right)$} & \multicolumn{2}{|c|}{$0,16 \pm 0,14$} & $0,09[0,06-0,24]$ & $0,15 \pm 0,1$ & $0,12[0,06-0,21]$ & $0,935^{*}$ \\
\hline \multicolumn{2}{|l|}{ 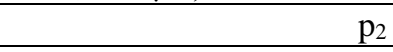 } & & $0,999 * *$ & & $0,004^{* *}$ & \\
\hline \multicolumn{2}{|l|}{ NE1/E01 } & \multicolumn{2}{|c|}{$84,98 \pm 81,99$} & $\begin{array}{c}69,33[22,87- \\
104,14] \\
\end{array}$ & $123,48 \pm 86,1$ & $96[51,44-178]$ & 0,174 \\
\hline \multicolumn{2}{|l|}{ NE2/EO2 } & \multicolumn{2}{|c|}{$84,98 \pm 81,99$} & $\begin{array}{c}69,33[22,87- \\
104,14]\end{array}$ & $60,81 \pm 70,74$ & $24,67[17,15-77,08]$ & 0,285 \\
\hline & & $\partial_{2}$ & & $0,999 * *$ & & $0,041^{* *}$ & \\
\hline $\mathrm{WBC} 1\left(\mathrm{x} 10^{3} / \mathrm{mL}\right)$ & & 11,0 & $\pm 7,89$ & $9,22[6,55-13,43]$ & $5,05 \pm 1,24$ & $5,07[4,02-6,12]$ & 0,007 \\
\hline $\mathrm{WBC} 2\left(\mathrm{x} 10^{3} / \mathrm{mL}\right)$ & & 11,0 & $\pm 7,89$ & $9,22[6,55-13,43]$ & $6,81 \pm 3,2$ & $5,95[4,28-7,6]$ & 0,062 \\
\hline & & 0 , & & & 0,059 & & \\
\hline $\mathrm{NE} 1\left(\mathrm{x} 10^{3} / \mu \mathrm{L}\right)$ & & 8,15 & 7,64 & $4,97[3,43-11,48]$ & $3,55 \pm 1,15$ & $3,32[2,47-4,63]$ & $0,009 *$ \\
\hline $\mathrm{NE} 2\left(\mathrm{x} 10^{3} / \mu \mathrm{L}\right)$ & & 8,15 & 7,64 & $4,97[3,43-11,48]$ & $4,84 \pm 3,48$ & $3,43[2,63-4,92]$ & $0,041 *$ \\
\hline & & $b_{2}$ & & $0,999 * *$ & & $0,394 * *$ & \\
\hline LYM1 $\left(x 10^{3} / \mu \mathrm{L}\right)$ & & 2,07 & 0,95 & $1,92[1,32-2,88]$ & $1,08 \pm 0,52$ & $0,87[0,65-1,39]$ & 0,001 \\
\hline LYM2 $\left(x 10^{3} / \mu \mathrm{L}\right)$ & & 2,07 & $=0,95$ & $1,92[1,32-2,88]$ & $1,39 \pm 0,69$ & $1,56[0,74-1,85]$ & 0,033 \\
\hline & & 0 , & & & 0,022 & & \\
\hline MO1 $\left(x 10^{3} / \mu \mathrm{L}\right)$ & & 0,63 &, 38 & $0,51[0,38-0,87]$ & $0,35 \pm 0,1$ & $0,33[\mathrm{C}$ & 0,010 \\
\hline MO2 $\left(x 10^{3} / \mu \mathrm{L}\right)$ & & 0,63 &, 38 & $0,51[0,38-0,87]$ & $0,41 \pm 0,16$ & $0,38[0,26-($ & 0,049 \\
\hline & & 0 , & & & 0,096 & & \\
\hline $\mathrm{BAS1}\left(\mathrm{x} 10^{3} / \mu \mathrm{L}\right)$ & & 0,08 & 0,05 & $0,08[0,04-0,1]$ & $0,03 \pm 0,02$ & $0,03[0,02-0,04]$ & $<0,001^{*}$ \\
\hline $\operatorname{BAS} 2\left(x 10^{3} / \mu \mathrm{L}\right)$ & & 0,08 & $=0,05$ & $0,08[0,04-0,1]$ & $0,03 \pm 0,02$ & $0,03[0,02-0,04]$ & $<0,001 *$ \\
\hline & & 0 , & & & & $0,859 * *$ & \\
\hline PLT1 & & 233,8 & 82,11 & $193,8[179,9-280]$ & $160,74 \pm 47,34$ & $169,6[127,2-186,7]$ & 0,006 \\
\hline PLT2 & & 233,8 & 32,11 & $193,8[179,9-280]$ & $261,51 \pm 100,87$ & $253,9[210,7-$ & 0,416 \\
\hline & & 0 , & & & 0,001 & & \\
\hline EO1\% & & 1,69 & 1,45 & $1,04[0,67-2,62]$ & $1,01 \pm 0,73$ & $0,96[0,52-1,14]$ & 0,113 \\
\hline $\mathrm{EO} 2 \%$ & & 1,69 & 1,45 & $1,04[0,67-2,62]$ & $2,27 \pm 1,59$ & $2,61[0,63-3,81]$ & 0,307 \\
\hline & & 2 & & $0,999 * *$ & & $0,041^{* *}$ & \\
\hline NE1 \% & & 66,9 & 6,57 & $63,94[52,08-82,71]$ & $69,68 \pm 10,24$ & $72,1[61$ & 0,594 \\
\hline NE2 \% & & 66,97 & 6,57 & $63,94[52,08-8$ & $66,12 \pm 14,61$ & $66,09[5$ & 0,882 \\
\hline & & 0 , & & & 0,226 & & \\
\hline LYM1 \% & & $24,3=$ & 14,31 & $23,46[9,5-37,27]$ & $21,59 \pm 9,03$ & $20[17,47-30,88]$ & 0,540 \\
\hline LYM2 \% & & $24,3=$ & 14,31 & $23,46[9,5-37,27]$ & $24,51 \pm 12,57$ & $26,27[17,4-34,18]$ & 0,967 \\
\hline & & 0 , & & & 0,273 & & \\
\hline MPV1 & & $8,8 \pm$ & & $8,7[8,3-9,4]$ & $8,88 \pm 0,62$ & $9[8,4-9,3]$ & 0,727 \\
\hline MPV2 & & $8,8 \pm$ & & $8,7[8,3-9,4]$ & $8,95 \pm 0,97$ & $8,8[8,3-9,4]$ & 0,626 \\
\hline & $\mathrm{p}_{2}$ & 0,9 & & & 0,822 & & \\
\hline NE/LYM1 & & $5,89 \pm$ & & $2,74[1,4-8,7]$ & $4,18 \pm 2,85$ & $3,45[1,87-4,23]$ & $0,653 *$ \\
\hline NE/LYM2 & & $5,89 \pm$ & & $2,74[1,4-8,7]$ & $7,27 \pm 11,26$ & $2,53[1,6-4]$ & 0,999* \\
\hline & $\mathrm{p}_{2}$ & & & $0,999 * *$ & & $0,570^{* *}$ & \\
\hline NE1/MO1 & & $4,7 \pm 14,16$ & & $2,43[6,43-16,06]$ & $10,17 \pm 3,52$ & $9,87[7,2-12,7]$ & $0,443^{*}$ \\
\hline NE2/MO2 & & $4,94 \pm 14,9$ & & $1,3[6,76-15,75]$ & $12,48 \pm 8,07$ & $9,8[7-13,67]$ & $0,787 *$ \\
\hline & \begin{tabular}{l|l}
$\mathrm{p}_{2}$ \\
\end{tabular} & & & $0,510^{* *}$ & & $0,281 * *$ & \\
\hline LYM1/MO1 & & $16 \pm 2,78$ & & ,58[1,79-5,9] & $3,01 \pm 1,32$ & $2,9[2,05-3,48]$ & $0,389 *$ \\
\hline LYM2/MO2 & & $14 \pm 2,68$ & & ,51[1,81-5,36] & $3,88 \pm 2,17$ & $3,64[1,74-6,05]$ & $0,983 *$ \\
\hline & $\mathrm{p}_{2}$ & & & $0,778^{* *}$ & & $0,211^{* *}$ & \\
\hline LYM1/CRP1 & $17,25 \pm$ & $\pm 33,75$ & $9,21[0$ & 0,39-16,63] & $, 8 \pm 0,65$ & $0,69[0,13-1,53]$ & $0,021 *$ \\
\hline LYM2/CRP2 & $17,25 \pm$ & $\pm 33,75$ & $9,21[0$ & $0,39-16,63]$ & $, 78 \pm 2,22$ & $1,02[0,6-2,2]$ & $0,061 *$ \\
\hline $\mathrm{p}_{2}$ & & & & $0,999 * *$ & & $\mathbf{0 , 0 3 1} * *$ & \\
\hline PLT1/LYM1 & & $153,81 \pm$ & 41,41 & $\begin{array}{c}111,48[76,65- \\
142,88] \\
\end{array}$ & $183,75 \pm 112,61$ & $149,3[97,85-213,45]$ & $0,106^{*}$ \\
\hline PLT2/LYM2 & & $153,81 \pm$ & 41,41 & $\begin{array}{c}111,48[76,65- \\
142,88]\end{array}$ & $253,68 \pm 186,74$ & $\begin{array}{c}205,14[144,59- \\
312,19]\end{array}$ & $0,026^{*}$ \\
\hline
\end{tabular}




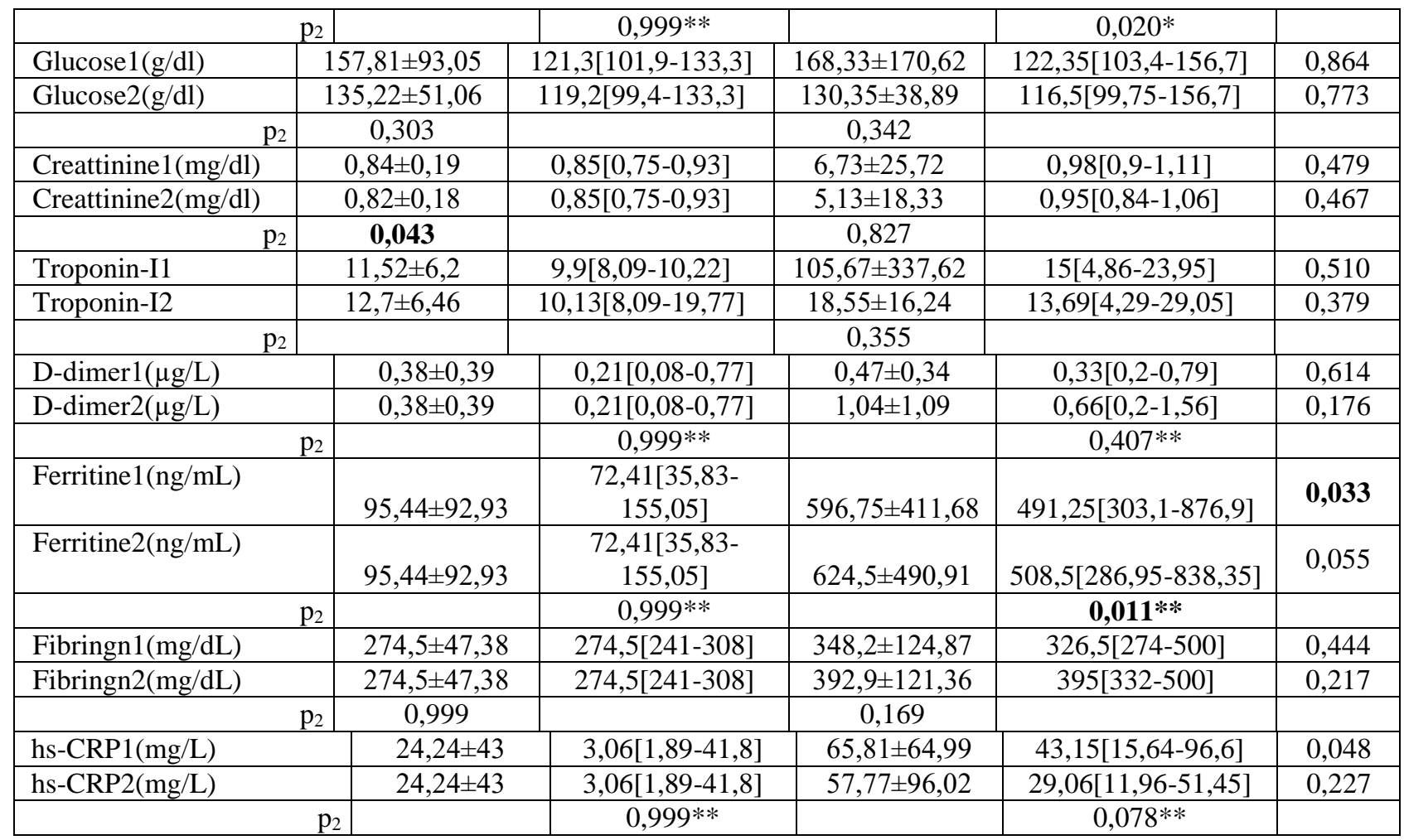

Data were presented as mean \pm standard deviation or median, quartile1, quartile3. p1: *: Mann Whitney U test was used. For others, the significance test of the difference between the two means was used. p2: **: Wilcoxon test, for others the difference between two spouses EO: Eosinophil, NE: Neutrophil, LYM: Lymphocyte, MO: Monocyte, BAS: Basophil, WBC: White Blood Cell, PLT: Platelet. Annex' 1 ' at the end of parameters refers to 'value on admission' while '2' refers to 'one week after admission'.

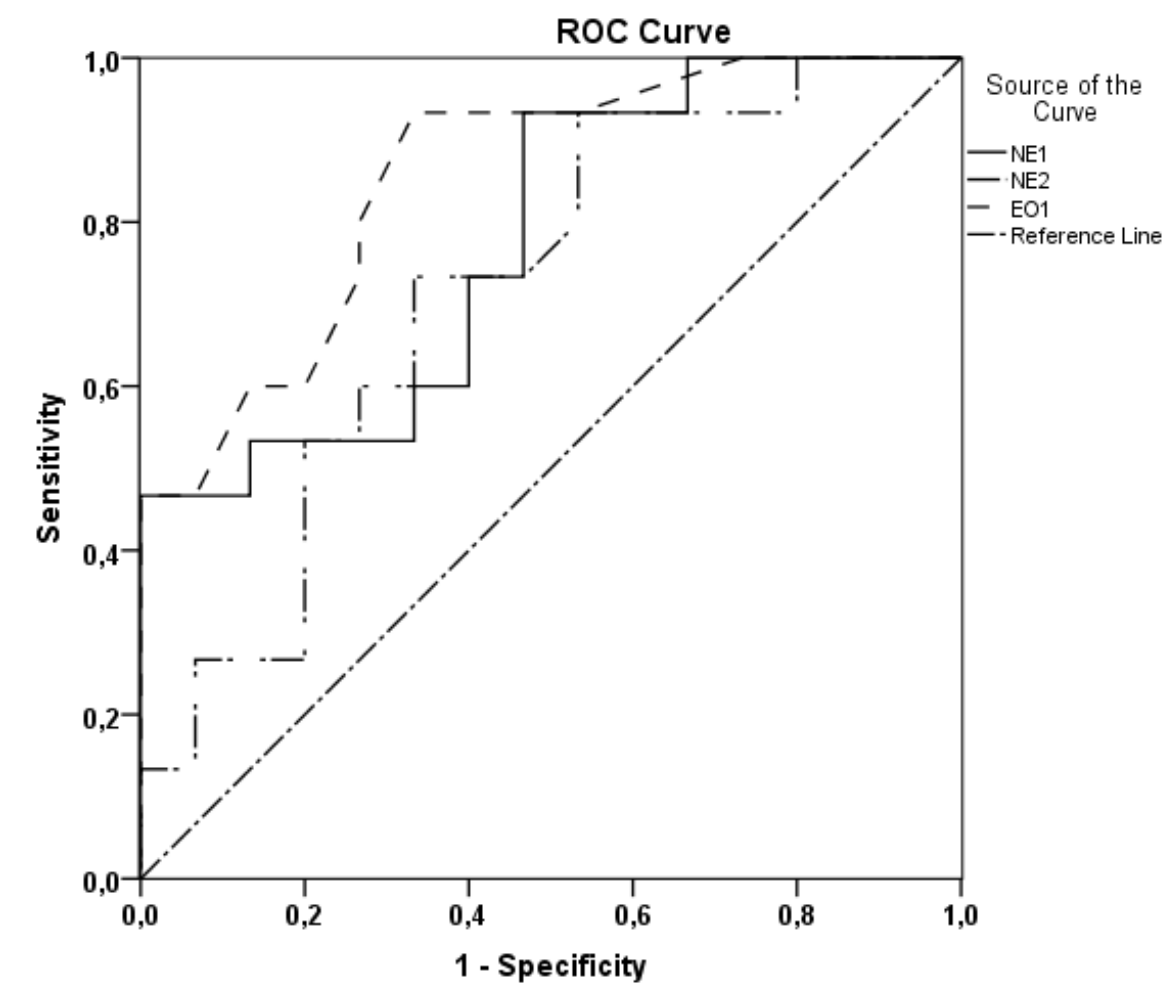

Figure 1: ROC curves for EO1, NE1 and NE2 


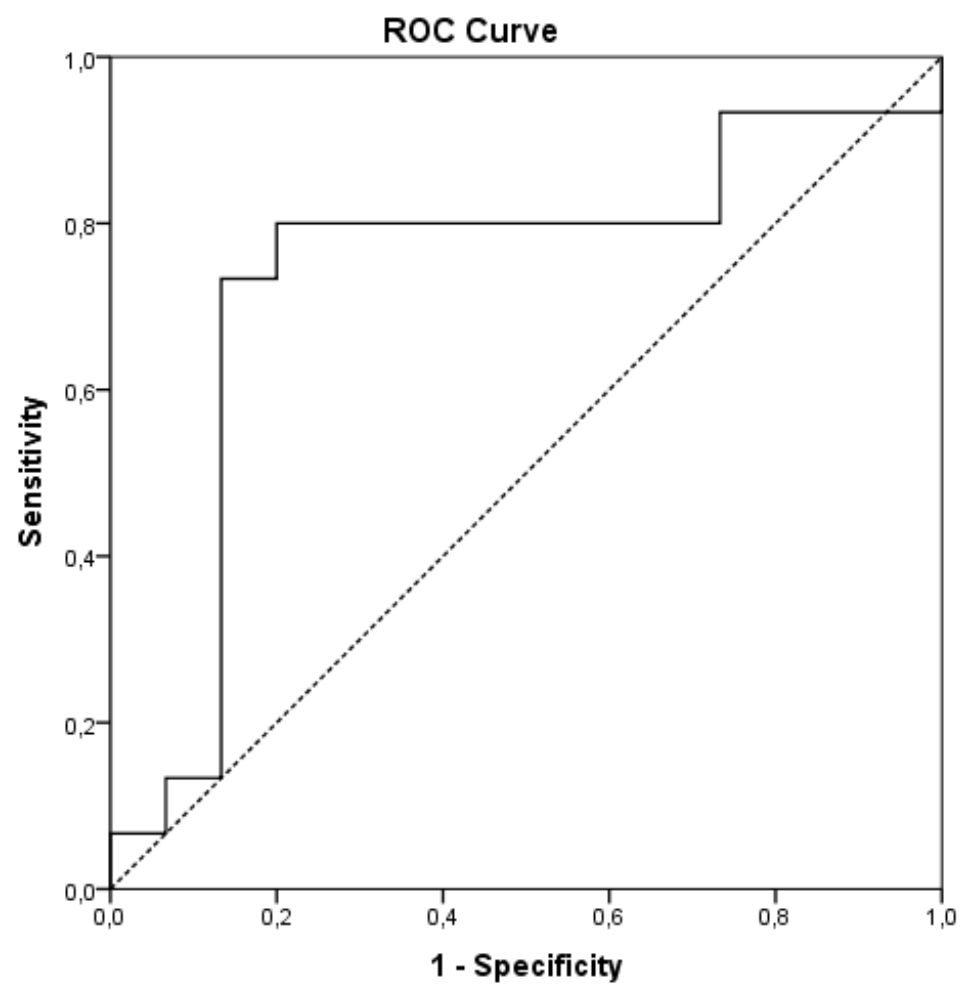

Figure 2: ROC curve for PLT2/LYM2

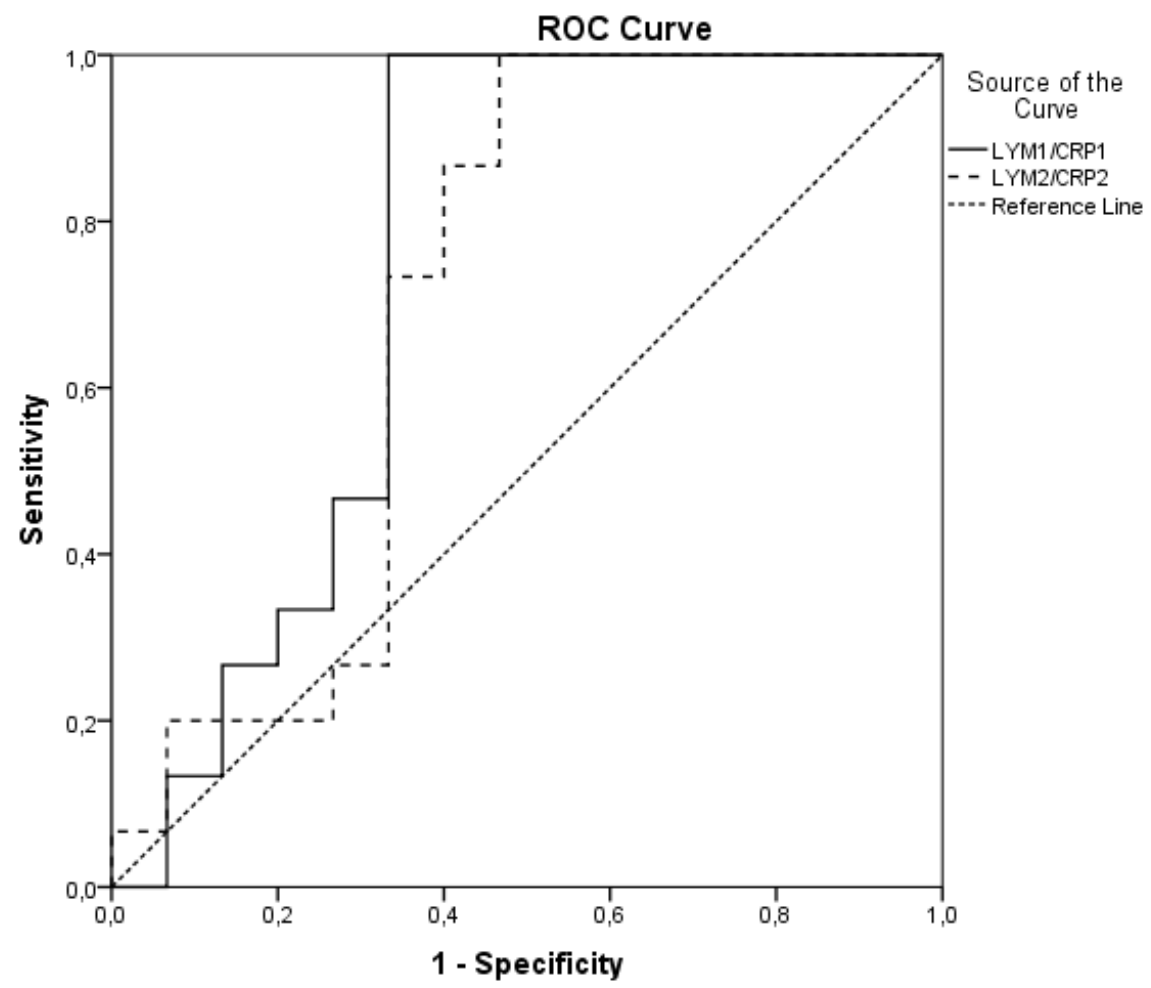

Figure 3: ROC curves for LYM1/CRP1 and LYM2/CRP2 


\section{DISCUSSION}

We investigated 30 Covid-19 patients applied to our hospital between 15 March and 15 June 2020 and 30 controls paired for age and sex. Mean ages of both groups were $57.2 \pm 15.46$ and $60.07 \pm 20.59$ respectively, indicating Covid-19 patients need admission to hospital were over 40s. That shows us that by aging body's defenses decrease due to deterioration of immune and physiological functions. In our study, $13.3 \%$ patients had chronic lung disease, 6.7\% had Diabetes Mellitus, 20\% had hypertension, $6.6 \%$ had Cardio-Vascular Disease, and $6.6 \%$ had any malignant disease. It demosnstrates us that, in elderly patients there are more underlying diseases and they increase severity of the disease and thereby increase admission to the hospital in the course of disease. Regarding clinical symptoms, $73.3 \%$ had fever, $33.3 \%$ had dispnea, $91.7 \%$ had coughing, and $80 \%$ of patients had malaise. We should concern about those patients who have these clinical to take some active measures like isolation and medical traetment to protect patients themselves and people around them.

When we look at the existing medical literature our results were in line with some following studies. Fu et al ${ }^{6}$ reported in their study that the most common complications were hypertension $(26.1 \%)$ and diabetes $(12.5 \%)$, which is consistent with the current understanding of the disease. The main clinical symptoms of patients in this study were fever $(80.7 \%)$, weakness $(48.9 \%)$, dry cough (36.4\%), and expectoration (31.8\%).

Zhang et $\mathrm{al}^{7}$ in their study found that in regard to clinical symptoms, $71(80.7 \%)$ patients had fever, 43 (48.9\%) had asthenia, $32(36.4 \%)$ had dry cough, 28 (31.8\%) had expectoration, 21 (23.9\%) had shivering and $15(17.0 \%)$ had muscle pain, and there was no significant difference in symptoms in the different groups. Among all patients, 33 $(37.5 \%)$ had underlying diseases, of which hypertension $(26.1 \%)$ and diabetes $(12.5 \%)$ were the most common.

Our CBC results were divided into two groups, as 'on admission' and 'one week later' results, in this study according to the real-time condition of the patients. Eosinophils (EOs), the Neutropil/ Eosinophil Ratios (NEU/EOs), Lymphocytes (LYMs), and Platelets (PLTs) showed a significant upward trend with one week after admisson. This also led to a significant increase in associated parameter, the Platelet/ Lymphocyte Ratio.

In the early stage of the Covid-19 disease, antibodies that directly combining and destroying the virus were secreted by $\mathrm{B}$ lymphocytes. $\mathrm{T}$ lymphocytes can eliminate the virus by engulfing infected cells. This process makes clear that the main reason for the decrease in lymphocytes may be consumption of a large number of lymphocytes ${ }^{8}$. In addition to this process, it has been showed in early changes in autopsy results that in acute lung injury during infection and diffuse alveolar injury with exudate, the inflammation was mainly lymphocytic and it also demonstrates the reason of decrease in lymphocytes ${ }^{9}$. During the course of disease, the organs that produce lymphocytes are also attacked or even destroyed by the virus and that is another reason of decrease of lymphocytes. At later stages, secondary bacterial infections takes place. Neutrophils are activated by the pathogen and release a large number of cytokines, chemokines, and various proteolytic enzymes to eliminate the pathogen and can lead to Acute Respiratory Distress Syndrome (ARDS). So that neutrophils are strongly related to the development of ARDS and critical illness ${ }^{10}$.

We evaluated efficacy of $\mathrm{CBC}$ indexes on admission to the hospital and one week later of admission in determining severity of the disease. EO1, NE1, NE2, PLT2/LYM2, LYM1/CRP1 and LYM2/CRP2 were the most predictive indexes. The AUCs of them were; 0.856, 0.778, 0.719, $0.738,0.747$ and 0.702 respectively, the cut-off values were; $0.04,3.32,3.21,144,59,1.99$ and 7.84 respectively, the sensitivity and specificity were $66.7 \%$ and $93.3 \%$ for EO1; $53.3 \%$ and $93.3 \%$ for NE1; $46.7 \%$ and $93.3 \%$ for NE2; and $80.1 \%$ and $80.5 \%$ for PLT2/LYM2; and for LYM1/CRP1; $100 \%$ and $66.7 \%$ and for LYM2/CRP2; $100 \%$ and $53.3 \%$ respectively. We will look over EO1 below in detail. According to our results; on admission to the hospital, our patients had a EO value lower than 0.04 , a NE value lower than 3.32, a LYM/CRP ratio lower than 1.99 and after a week of admission to the hospital our patients had a NE value lower than 3.21, LYM/CRP ratio lower than 7.84 and a PLT/LYM ratio over 144,59.

Both Neytrophil/Lymphocyte Ratio (NLR) and Platelet/Lymphocyte Ratio (PLR) are sensitive biomarkers of natural and systemic inflammation and, considered indicators of infection and systemic inflammation with all other CBC subset. Since our NLR values were not significant, we will focus on PLR in detail. There are some studies consistent with our findings as follow.

Bastug et al ${ }^{11}$. in their retrospective study investigating 191 hospitalized patients, found that PLR had a c1-off value of over 175.78 with AUC of 71.5 , sensitivity of $75.6 \%$ and specificity of 57.2 
and NE had a cut-off value of over 4.11 with AUC of 82.5 , sensitivity of $84.4 \%$ and specificity of 66.2 on admmission.

$\mathrm{Lu}$ et $\mathrm{al}{ }^{12}$, in their study, investigated the epidemiological history, diagnosis and treatment process, as well as dynamic changes in routine blood indicators, of a severe COVID-19 patient hospitalized for 26 day and have shown that the patient's condition worsened in the first week after admission, Neutrophils, lymphocytes, monocytes, eosinophils, and platelet lymphocyte ratio (PLR) decreased. After seven day of admission, these cells decreased to their lowest values. Neutrophil, CRP, monocyte and PLR decreased gradually on 20th day of admission. Within 10 days after admission; monocytes and eosinophils were at extremely low levels. Eosinophils recovered earlier than other parameters in about 12 days after admission and they interpreted this condition in such a way that it might be of great value in judging the progress of the disease.

Qu et al ${ }^{13}$ in their study; case series of the 30 hospitalized patients with confirmed coronavirus disease (COVID)-19 in Huizhou municipal central hospital from January 2020 to February 2020 were retrospectively analyzed. Severe patients and nonsevere patients were compared in terms of outcomes. They showed that the PLR value at peak platelet during treatment was an independent influencing factor in severe patients. They have demostrated that patients with significantly elevated platelets during treatment had longer average hospitalization days as well as average hospitalization day of patients with platelet peaks during treatment was longer than those without platelet peaks. At the end, they have presumed that during the treatment the number of platelets and their dynamic changes may have a suggestion on the severity and prognosis of the disease. The PLR, markedly elevated platelets and longer average hospitalization days may be related to the cytokine storm. The PLR might provide a new indicator in the monitoring in patients with COVID-19.

Wang et al ${ }^{14}$ conducted a study. The epidemiological indexes, clinical symptoms, laboratory test results and clinical data of 45 moderate and severe type patients with severe acute respiratory syndrome coronavirus 2 (SARSCoV-2) infections in Jingzhou Central Hospital from January 23 to February 13, 2020 were retrospectively analyzed. During disease progressed, WBC, neutrophil count, and PLR parameters in the severe group were significantly higher than those in the moderate group; at the same time, lymphocyte count (Lym\#), eosinophil count (Eos\#), parameters in the severe group were significantly lower than those in the moderate group. For PLR parameter, it's AUC, cutoff, sensitivity and specificity were $0.842,267.03$, $83.3 \%$ and $74.0 \%$ respectively.

Kazancioglu et al ${ }^{15}$, in their study, have evaluated the laboratory data of 120 COVID-19 patients, 100 influenza patients and 61 healthy controls. They have found lower lymphocytes, eosinophils, basophils, platelets and higher delta neutrophil index (DNI), neutrophil-to-lymphocyte ratio (NLR) and platelet-to-lymphocyte ratio (PLR) in COVID-19 and influenza groups compared to healthy controls. They figured out that the highest contribution to differentiate COVID-19 patients from healthy controls (area under the curves (AUCs): $0.819,0.817$ and 0.716, respectively; Pvalue is $<0.0001$ for all) was made by eosinophils, lymphocytes and PLR. For NLR, the optimal cutoff value was 3.58, with a sensitivity of 30.8 and a specificity of 100 (AUC:0.677, P < 0.0001). At the end of treatment; higher leucocytes, neutrophils, PLR and lower lymphocytes, levels were found in severe patients. In severe patients, there was an upward trend for eosinophils, platelets and PLR. They concluded that, NLR and PLR can be used as biomarkers to distinguish COVID-19 patients from healthy people and to predict the severity of COVID-19. In prediction of disease severity; the increasing value of PLR during follow-up may be more useful compared to NLR.

A meta-analysis of Chan et al ${ }^{16}$ to estimate standard mean difference (SMD) of NLR and PLR values with $95 \%$ confidence interval (CI) between severe and non-severe COVID-19 cases has concluded that nineteen studies reported NLR values, while five studies reported PLR values between severe and non-severe COVID-19 patients. Higher levels of NLR (SMD: $2.80,95 \%$ CI: 2.12 - 3.48, P < 0.00001) and PLR (SMD: 1.82, 95\% CI: $1.03-2.61, \mathrm{P}<0.00001)$ ) were found in patients with severe disease compared to nonsevere disease. It ha been postulated that, in COVID-19, NLR and PLR can be used as independent prognostic markers of disease severity. As we said above we looked in detail an important $\mathrm{CBC}$ subset eosinophil in detail.

In a meta-analysis of Lagunas ${ }^{17}$, the LYM/CRP ratio values were decreased significantly $(\mathrm{SMD}=$ $-0.912,95 \% \mathrm{CI}=-1.275$ to -0.550$)$. IN consistent with our results they concluded that increased low LYM/CRP ratio levels reflecting an enhanced inflammatory process may suggest a poor prognosis.

The role of eosinophils in inflammation is remarkable in Covid-19 disease ${ }^{18}$. Eosinophils are 
proinflammatory leukocytes.. Eosinophils produce a wide variety of cytokines, chemokines, and lipid mediators, and therefore, in addition to being an effector cell, they play an immunoregulatory role in inflammatory processes and participate in tissue modification ${ }^{19}$.

Eosinopenia has been associated with many inflammatory diseases such as SARS. The eosinophil reduction in Covid-19 patients may be associated with high SARS-Cov2 viral load and SARS-Cov2-initiated consumption of eosinophil granule protein. Rapid and long-term duration of eosinophil decrease is an indicator of the physiological response to acute inflammation ${ }^{20}$. Eosinopenia may also occur in response to various triggers of acute inflammation such as sepsis. Eosinopnia is an independent predictor of death from pneumonia, but this does not apply to chronic lung diseases ${ }^{21}$.

Observational studies in Covid-19 patients have revealed that increased eosinophil amounts are associated with good results, while eosinopenia is seen in more severe cases ${ }^{22}$. Eosinopenia has been reported in $50-70 \%$ of severe Covid-19 patients. Eosinophilic inflammation was observed in a minority of Covid-19 infection ${ }^{23}$.

Since the beginning of the Covid-19 pandemic, eosinopenia or low amount of eosinophils $\left(<0.01 \times 10^{9} / \mathrm{L}\right)$ has been observed in most hospitalized patients and has been found to be associated with the severity of the disease. Eosinopenia was observed in $79 \%$ of PCRconfirmed SARS-Cov2 positive patients $(\mathrm{n}=52)$ and $36 \%$ of SARS-Cov2 negative patients. It has been observed that a single simple laboratory parameter can be useful in early screening of Covid-19. Also, 10 of 13 patients had a 0.0 eosinophil count or 7 of 10 patients presented with eosinophil cytopenia ${ }^{18}$. Moreover, eosinopenia has been found to be associated with poor prognosis ${ }^{24}$.

In line with the existing literature, our patients showed eosinopenia at the time of admission and eosinophil counts increased at the end of first week of treatment compared to the admission, confirming our assumption that it may have a diagnostic count in Covid-19 patients. Three (20\%) patients who died had eosinopenia both at the time of admission and after the first week of treatment.

Some studies have used absolute eosinophil counts. However, since the absolute eosinophil counts may vary between different laboratories, we preferred to calculate the Neutrophil / Eosinophil ratio (NE / EO) instead of the absolute eosinophil count in order to achieve standardization in our study. In the patient group, the NE2 / EO2 ratios after one week of treatment were found to be significantly lower than that of admission $(\mathrm{NE} 1 / \mathrm{EO} 1)(\mathrm{p}=0.041)$. Our results have shown that eosinophil count of first week (EO2) had significantly, positive directional modarete correlation with lymphocyte count of a week later (LYM2) (r: 0.594, $\mathrm{p}=0.020$ ) This correlation showed us that eosinopenia and lymphopenia were compatible. Lymphopenia is also common in Covid-19, and blood eosinophil counts are also positive corrolated with lymphocyte levels in mild and severe coronavirus cases ${ }^{25}$.

In our study, both the neutrophil counts of the patients at the time of admission (NE1) and one week later (NE2) were significantly lower than the controls $(\mathrm{p}=0.009, \mathrm{p}=0.041$, respectively). Our results showed a significant, very strong positive directional correlation of neutrophyl counts of one week later ( NE2) with leukocytes (WBC2) (r: $0.973, \mathrm{p}<0.001)$. Lymphocyte counts of the patients were significantly lower than controls, both at the time of admission (LYM1) and one week later (LYM2) $(\mathrm{p}=0.001, \mathrm{p}=0.033$, respectively).

Liu et al ${ }^{26}$ reported that in a small cohort of patients, eosinopenia was present on admission to hospital, improved compared to admission upon discharge, and this was an indicator of the correlation of improved eosinopenia with the improved clinical condition.

In line with these studies, our patients had eosinopenia at the time of presentation and it was observed that the eosinophil counts, after one week, improved significantly compared to the admission levels $(\mathrm{p}=0.004)$.

In our study; 3 (20\%) patients had leukopenia, 8 (53.3\%) patients had both lymphopenia and eosinopenia on admission. All of our 15 (100\%) patients had high hs-CRP levels. In the controls; lymphopenia, eosinopenia and high hs-CRP levels were seen in $2(13 \%), 7(46.7 \%)$ and $6(40 \%)$ respectively. hs-CRP was significantly higher in patients than controls on admission $(\mathrm{p}=0.048)$.

$\mathrm{Li}$ et al. ${ }^{27}$ reported that the combination of eosinopenia and hs-CRP can be used in triage of highly suspected patients. In cases where CT or PCR is not available, "normal or decreased leukocyte or lymphopenia" is not very effective in distinguishing Covid-19 from other patients with fever and respiratory symptoms. Because normal or low leukocyte or lymphopenia is not specific for Covid-19 and can be seen in other communityacquired viral pneumonias. In suspected cases, eosinopenia and high hs-CRP are simple laboratory 
tests, which are also included in the WHO's interim guideline ${ }^{28}$.

Our results are also in line with these data. In the initial evaluation phase of suspicious patients with Covid-19-like complaints, it has been observed that eosinopenia can be used alone or in combination with hs-CRP in order to prioritize suspected patients for PCR or CT or when the result takes a long time to come out. Eosinophil count enables health professionals isolate the patient quickly and initiate empirical treatment. It seems that a simple hemogram test showing eosinopenia can be of great benefit in rapid diagnosis and treatment in emergency situatian.

In different countries, the mortality rates are quite different due to differences in prevention and control measures, with rates of 5.91\% (80 787/1 367 638), $10.06 \%$ (26.621/264.663), $14.53 \%$ (31.855/219. 183), $13.95 \%(30.560 / 219.070)$, and $16.41 \%(34.306 / 209.070)$ in the United States, Spain, the UK, Italy and Russia, respectively (7). In our study, we found our mortality rate as $10 \%$ $(3 / 30)$, and 27 (90\%) patients recovered and were discharged.

Ou study has some limitations; some records of patients' were missing so that we could not reach some datas. Since our hospital's Covid-19 case number was low, our results require validation with larger prospective cohorts.

As we all know, elder people with chronic diseases are more susceptible to COVID-19 and have a high likelihood of developing severe and critically severe infection. Levels of WBC, lymphocytes, neutrophils, CRP, NLR, PLR, troponin-I, and creatinine are important indicators for severity grading in COVID-19. We can say that EO, NE, CRP, LYM/CRP and PLT/LYM can be used as biomarkers to distinguish COVID-19 patients from healthy people and to predict the severity of COVID-19.

In addition to other CBC subsets, it will be of great benefit for public health that suspected patients who apply to the Covid-19 outpatient clinic, are quickly isolated from other patients with similar symptoms, with a simple hemogram parameter, eosinophil count, and immediately initiated empirical treatment.

\section{Acknowledgments}

We thanks to our laboratory and data processing staff of our hospital.

\section{Conflict of Interest}

All authors state that there is no conflict of interest.

\section{REFERENCES}

1. Zhu N, Zhang D, Wang W. China Novel Coronavirus Investigating and Research Team. A novel coronavirus from patients with pneumonia in China, 2019 [published January 24, 2020]. N Engl J Med.

2. Jebril N. World Health Organization declared a pandemic public health menace: A systematic review of the coronavirus disease 2019 "COVID19", up to 26th March 2020. Available at SSRN 3566298. 2020.

3. Rothenberg ME, Hogan SP. The eosinophil. Annual review of immunology. 2006;24.

4. Weller PF, Spencer LA. Functions of tissueresident eosinophils. Nature Reviews Immunology. 2017;17(12):746-60.

5. Busse W, Chupp G, Nagase H, Albers FC, Doyle S, Shen Q, et al. Anti-IL-5 treatments in patients with severe asthma by blood eosinophil thresholds: Indirect treatment comparison. Journal of Allergy and Clinical Immunology. 2019;143(1):190-200. e20.

6. Fu L, Fei J, Xiang H-X, Xiang Y, Tan Z-X, Li $\mathrm{M}-\mathrm{D}$, et al. Influence factors of death risk among COVID-19 patients in Wuhan, China: a hospitalbased case-cohort study. MedRxiv. 2020.

7. Zhang H, Cao X, Kong M, Mao X, Huang L, He $\mathrm{P}$, et al. Clinical and hematological characteristics of 88 patients with COVID-19. International journal of laboratory hematology. 2020;42(6):7807.

8. Yang X, Yu Y, Xu J, Shu H, Liu H, Wu Y, et al. Clinical course and outcomes of critically ill patients with SARS-CoV-2 pneumonia in Wuhan, China: a single-centered, retrospective, observational study. The Lancet Respiratory Medicine. 2020.

9. Hanley B, Lucas SB, Youd E, Swift B, Osborn M. Autopsy in suspected COVID-19 cases. Journal of clinical pathology. 2020;73(5):239-42.

10. Wu C, Chen X, Cai Y, Zhou X, Xu S, Huang $\mathrm{H}$, et al. Risk factors associated with acute respiratory distress syndrome and death in patients with coronavirus disease 2019 pneumonia in Wuhan, China. JAMA internal medicine. 2020.

11. Bastug A, Bodur H, Erdogan S, Gokcinar D, Kazancioglu S, Kosovali BD, et al. Clinical and laboratory features of COVID-19: predictors of severe prognosis. International immunopharmacology. 2020;88:106950. 
12. Lu G, Wang J. Dynamic changes in routine blood parameters of a severe COVID-19 case. Clinica Chimica Acta. 2020.

13. Qu R, Ling Y, Zhang Yhz, Wei Ly, Chen X, Li $\mathrm{Xm}$, et al. Platelet-to-lymphocyte ratio is associated with prognosis in patients with coronavirus disease-19. Journal of medical virology. 2020.

14. Wang C, Deng R, Gou L, Fu Z, Zhang X, Shao $F$, et al. Preliminary study to identify severe from moderate cases of COVID-19 using combined hematology parameters. Annals of translational medicine. 2020;8(9).

15. Kazancioglu S, Bastug A, Ozbay BO, Kemirtlek N, Bodur H. The role of haematological parameters in patients with COVID-19 and influenza virus infection. Epidemiology \& Infection. 2020;148.

16. Lagunas-Rangel FA. Neutrophil-tolymphocyte ratio and lymphocyte-to-C-reactive protein ratio in patients with severe coronavirus disease 2019 (COVID-19): A meta-analysis. Journal of medical virology. 2020.

17. Lagunas-Rangel FA. Neutrophil-tolymphocyte ratio and lymphocyte-to-C-reactive protein ratio in patients with severe coronavirus disease 2019 (COVID-19): A meta-analysis. Journal of medical virology. 2020.

18. Rodriguez C, Veciana C. ASTHMA AND COVID-19: THE EOSINOPHILIC LINK. Qeios. 2020.

19. Akuthota P, Wang H, Spencer L, Weller P. Immunoregulatory roles of eosinophils: a new look at a familiar cell. Clinical \& Experimental Allergy. 2008;38(8):1254-63.

20. Bass DA, Gonwa TA, Szejda P, Cousart MS, DeChatelet LR, McCall CE. Eosinopenia of acute infection: production of eosinopenia by chemotactic factors of acute inflammation. The Journal of clinical investigation. 1980;65(6):126571.

21. Echevarria C, Hartley T, Nagarajan T, Tedd H, Steer J, Gibson GJ, et al. 30 day mortality and eosinopenia in patients with pneumonia. European Respiratory Journal. 2014;44(Suppl 58).

22. Du Y, Tu L, Zhu P, Mu M, Wang R, Yang P, et al. Clinical features of 85 fatal cases of COVID-19 from Wuhan. A retrospective observational study. American journal of respiratory and critical care medicine. 2020;201(11):1372-9.

23. Zhang J-j, Dong X, Cao Y-y, Yuan Y-d, Yang Y-b, Yan Y-q, et al. Clinical characteristics of 140 patients infected with SARS-CoV-2 in Wuhan, China. Allergy. 2020.

24. Du Y, Tu L. Clinical Features of 85 Fatal Cases of COVID-19 from Wuhan. A Retrospective Observational Study. 2020;201(11):1372-9.

25. Li X, Xu S, Yu M, Wang K, Tao Y, Zhou Y, et al. Risk factors for severity and mortality in adult COVID-19 inpatients in Wuhan. Journal of Allergy and Clinical Immunology. 2020.

26. Yao X, Zeng $\mathrm{Y}$, Tong $\mathrm{Y}$, Tang $\mathrm{X}$, Yin Z. Determination and analysis of blood eosinophil in 200 severe acute respiratory syndrome patients. Lab Med. 2004;5(19):444-45.

27. Li Q, Ding X, Xia G, Chen H-G, Chen F, Geng $\mathrm{Z}$, et al. Eosinopenia and elevated C-reactive protein facilitate triage of COVID-19 patients in fever clinic: a retrospective case-control study. EClinicalMedicine. 2020:100375.

28. Organization WH. Clinical management of severe acute respiratory infection when novel coronavirus $\quad(\mathrm{nCoV})$ infection is suspected: interim guidance, 25 January 2020. World Health Organization, 2020. 